\title{
En ung kvinne med langvarig diaré og slapphet
}

\author{
Diaré og slapphet er vanlige symptomer med mange differensialdia- \\ gnoser. En grundig reiseanamnese kan gi viktige ledetråder til riktig \\ utredning og diagnose.
}

En tidligere frisk kvinne i 20 -årene henvendte seg til fastlegen på grunn av langvarig diaré. I konsultasjonen fortalte hun at hun de siste seks månedene hadde vært plaget med diaré, vekslende fra to til seks tømminger daglig. Hun beskrev tidvis imperativ avføringstrang med eksplosive, vandige diareer som kunne være slimtilblandet. Hun hadde ikke observert blod, men hadde sett ufordøyede matrester i avføringen. Hun hadde ikke hatt feber eller følt seg egentlig syk, men var generelt slapp. Hun rapporterte borborygmi og at hun følte seg oppblåst i magen. Hun hadde ikke hatt magesmerter eller oppkast og var heller ikke gått ned i vekt.

Det var ikke opphopning av mage-tarmsykdom i familien, bortsett fra at et familiemedlem hadde hatt langvarige mageplager som var diagnostisert til à være irritabel tarm-syndrom. Pasienten var ikke kjent med at noen andre $i$ hennes nærmiljø hadde tilsvarende plager. Hun tenkte selv at det kunne være matvarer hun ikke tålte. For symptomlindring hadde hun forsøkt loperamid og probiotika, uten særlig effekt. Utover dette hadde hun ikke brukt medikamenter i perioden hun hadde vært plaget.

En rekke differensialdiagnoser er aktuelle ved kronisk diaré. Hos yngre mennesker er irritabel tarm og inflammatorisk tarmsykdom vanlige årsaker. Et av pasientens familiemedlemmer hadde irritabel tarm-syndrom, men hun selv hadde ikke hatt et forstyrret avføringsmønster med veksling mellom diaré og forstoppelse, som er vanlig ved denne tilstanden. Ulcerøs kolitt forårsaker ofte blod og puss i avføringen og kan gi langt hyppigere tømminger enn det pasienten hadde. Crohns sykdom kan gi ublodig diaré

Ved matvareintoleranse og matvareallerg er diaré, magesmerter, oppblåsthet, kvalme og oppkast vanlige symptomer. Cøliaki kan debutere i voksen alder etter lengre tids subklinisk forløp. Typiske symptomer er illeluktende, voluminøs eller fettglinsende avføring, oppblåst mage og flatulens. Gallesteinssykdom og pankreatitt vil i regelen gi sterke magesmerter. Medikamentbivirkninger og misbruk av laksantia må heller ikke glemmes som årsaker til kronisk diaré (1).
På spørsmål om utenlandsreiser fortalte pasienten at hun hadde vært på ferietur til et nordafrikansk land seks måneder tidligere. Hun var imidlertid usikker på om hun hadde hatt løs avføring før hun reiste på denne turen. Hun hadde ikke vært syk under oppholdet, men hadde hatt en periode med slapphet og dårlig allmenntilstand i flere uker etter at hun kom hjem. I den samme perioden mistet hun menstruasjonen $i$ tre måneder. Flere graviditetstester var negative og menstruasjonen var normal igjen på tidspunktet for første konsultasjon. Hun var likevel fortsatt slapp og orket ikke trene, slik hun alltid hadde gjort.

Ved undersøkelsen var pasienten igod allmenntilstand. Respirasjonen var ubesværet og normofrekvent og pulsen normal. Hun hadde upåfallende slimhinner i munnen og det var normal turgor $i$ huden. Ved klinisk undersøkelse av abdomen var det normale funn. Vekten var $57 \mathrm{~kg}$.

Reisen, som i tid kunne sammenfalle med sykdomsdebuten, forsterket mistanken om infeksiøs årsak til symptomene. Infeksjon med patogene tarmbakterier ses ikke sjelden i allmennpraksis. Sjeldnere årsaker er tarmparasitter som f.eks. Giardia lamblia, som vanligvis gir mer langvarig diaré og illeluktende flatulens enn patogene tarmbakterier (2). Tropisk sprue er en malabsorspsjonstilstand som kan gi kronisk diaré, slapphet og vekttap (3). Dette ble vurdert som mindre sannsynlig hos vår pasient, siden hun ikke hadde hatt vekttap.

Det ble tatt blodprøver og fecesprøve til dyrking av patogene tarmbakterier og undersøkelse på F-kalprotektin. Kontrolltime ble avtalt etter ti dager.

Da pasienten kom til kontrolltimen, var symptomene uforandret. Blodprøvene, inkludert leverprøver, hemoglobin og leukocytter med differensialtelling, var alle normale. S-TSH var normal og s-matvareallergi var negativ. Avføringsprøver viste ingen vekst av Salmonella, Shigella, Yersinia eller Campylobacter. F-kalprotektin var normal.

De negative prøvesvarene styrket mistanken om mer uvanlig årsak til pasientens vedvarende vanntynne diaré, slik som parasittsykdom eller mikroskopisk kolitt.

\author{
Kurt Hanevik \\ kurt.hanevik@med.uib.no \\ Nasjonal kompetansetjeneste for tropiske \\ infeksjonssykdommer \\ Medisinsk avdeling \\ John Olav Alvsvåg \\ Mikrobiologisk avdeling \\ Gades institutt \\ Haukeland universitetssykehus
}

\section{Ketil Kvanum Sund}

Legehuset Varden

> Se kommentar side 192 


\section{Livssyklusen til Heterophyes heterophyes}

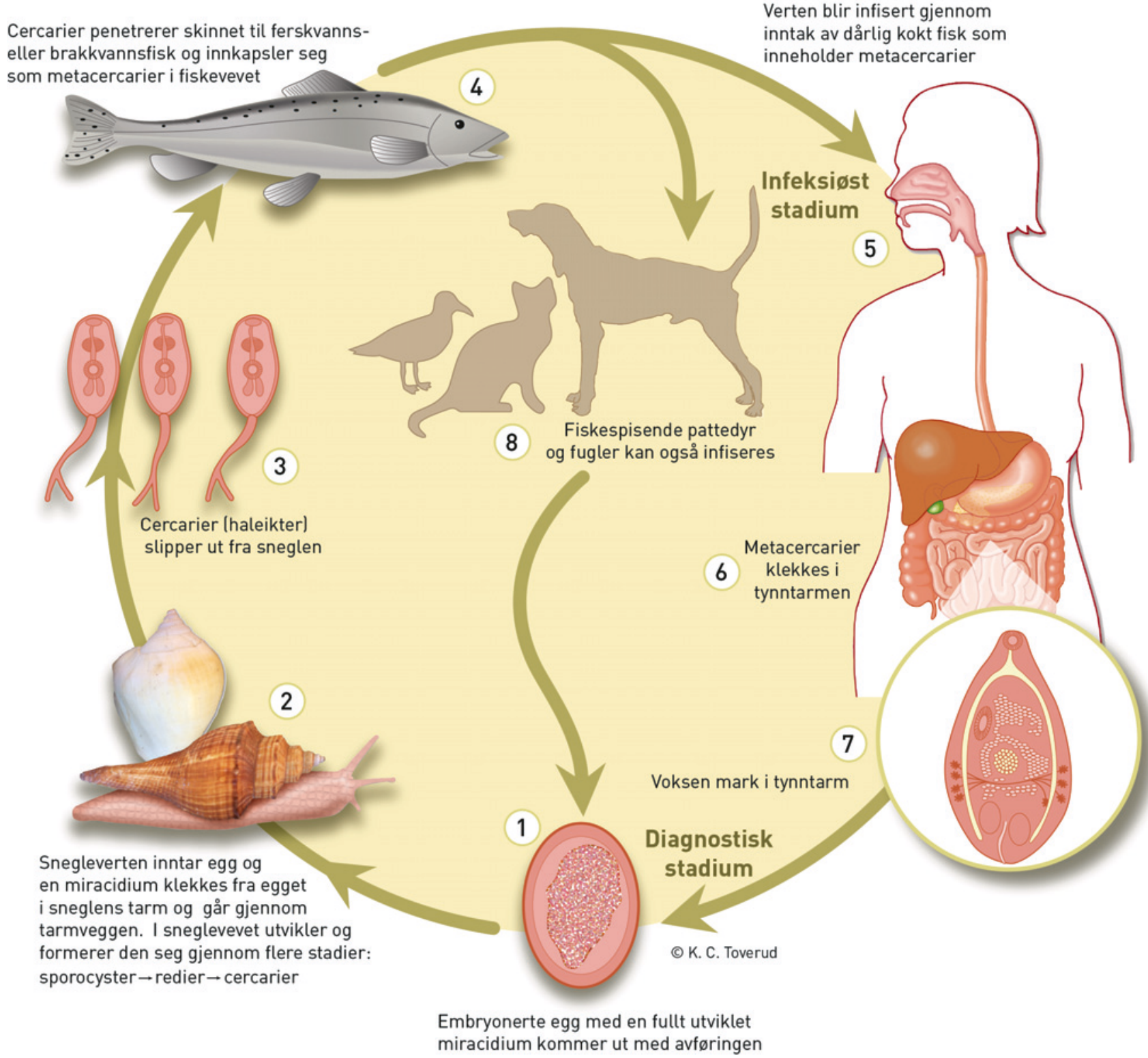

Figur 1 H. heterophyes' livssyklus

Pasienten ble derfor henvist til koloskopi med tanke på kolitt, og det ble sendt inn to avføringsprøver til mikroskopi for undersøkelse med tanke på parasitter. Mikroskopien viste små egg som, på bakgrunn av størrelse, form og reisen til det nordafrikanske landet, ble bestemt til å være fra en liten tarmikte (trematode): Heterophyes heterophyes. Pasienten fikk dagen etter poliklinisk time ved universitetssykehus.

Selv om man fant diagnosen, ble pasienten henvist til universitetssykehuset. Dette ble gjort fordi man ønsket erfaring med slike importerte infeksjoner ved universitetssyke- huset og det var et lite lager av praziquantel (4) tilgjengelig der.

Det fremkom under denne konsultasjonen at kvinnen og samboeren hadde spist sushi ved to anledninger i løpet av utenlandsoppholdet, første gang like etter at de var ankommet feriestedet. Etter at hun hadde fått tenkt litt over symptomstart hadde hun kommet frem til at diaréplagene startet om kvelden den dagen hun kom hjem, da hun ikke hadde kunnet gå i et planlagt selskap.

Vår pasient fikk $40 \mathrm{mg} / \mathrm{kg}$ praziquantel (Biltricide), altså fire tabletter à $600 \mathrm{mg}$ fordelt på tre doser $(2+1+1)$ i løpet av en dag.
Allerede tre dager senere følte hun seg bedre. Ved telefonoppfølging 14 dager etter behandlingen var hun betydelig bedre, men hadde fortsatt litt hyppig avføring. Ved kontroll fire uker senere var hun helt bra. Hun sa da at det var først da hun fikk tilbake energien at hun forsto hvor dårlig hun egentlig hadde vært. Det ble tatt tre nye avføringsprøver, men det kunne ikke lenger påvises egg eller cyster. Videre utredning ble ikke vurdert å være nødvendig, og koloskopitimen ble avbestilt.

Svekket immunforsvar gir økt risiko for infeksjoner. Bakenforliggende immunsvikt 
bør derfor has in mente ved hyppige eller uvanlige infeksjoner. Vår pasient viste ikke tegn til svekket immunforsvar, og hun kom seg raskt med behandling. Videre utredning ble derfor ikke vurdert som nødvendig.

Pasientens samboer hadde ikke hatt noen mageplager, men fikk også påvist $H$. heterophyes i avføringsprøver. Han ble behandlet på samme måte og hadde negative avføringsprøver etter behandling med samme dosering av praziquantel.

\section{Diskusjon}

Trematoder, på norsk kalt flatormer eller ikter, kan gi sykdom hos mennesker og dyr med sin tilstedeværelse i galleganger ( $F a c i-$ ola hepatica, Clonorchis sinensis), i vener i tarm- og blærevegg (Schistosomiasis spp.), i lunger (Paragonimus westermani) eller i tarmepitel (f.eks. Fasciolopsis buski, Metagonimus spp., Heterophyes spp.) (5-8).

Det er rapportert at det finnes omkring 70 iktearter som kan kolonisere tarmen hos mennesker. De fleste tilhører familiene Heterophyidae - som Heterophyes spp. - og Echinostomatidae (6), mens F. buski og Metagonimus spp. tilhører andre familier. Størrelsen varierer fra noen få millimeter til $7 \mathrm{~cm}$. Disse intestinale iktene er utbredt over hele verden, men prevalensen er høyest i Østog Sørøst-Asia. Med unntak av enkelte rapporterte tilfeller av innenlands smitte (9) vil de aller fleste tilfeller være importert, da mellomvertene ikke finnes i Norge og den hygieniske standard forebygger smitte.

$H$. heterophyes er den minste trematoden som infiserer mennesker - den voksne marken måler bare $0,3 \mathrm{~mm} \times 1-2 \mathrm{~mm}(10)$. Den forårsaker tarminfeksjoner i Midtøsten, og spesielt i Egypt, Sudan og Iran. En studie fra Egypt viste at $32 \%$ av brakkvanns- og ferskvannsfisken var infisert, og prevalensen $i$ befolkningen var $13 \%$ (11). Andre Heterophyes-arter er endemiske i tropiske områder i Øst-Asia og Korea (6).

\section{Livssyklus}

Heterophyes' livssyklus er beskrevet i figur 1. Snegleartene Certithidia (Asia) og Pironella (Midtøsten) er vanligste mellomverter (6). Disse inntar feces fra en infisert vert og får slik i seg egg (fig 2) som inneholder fullt utviklede miracidier. Miracidiene trenger inn i sneglens tarmvegg, hvor de formerer seg og går gjennom forskjellige utviklingsstadier (sporocyste, redie) og gir opphav til et stort antall cercarier. Cercariene frigjøres fra sneglene, penetrerer skinnet til fersk- og brakkvannsfisk og omdannes til metacercarier i fiskevevet.

Ved å spise ukokt eller dårlig kokt fisk, vanligvis muller eller små ferskvannskarper (som ørekyte), kan en rekke fiskespisende

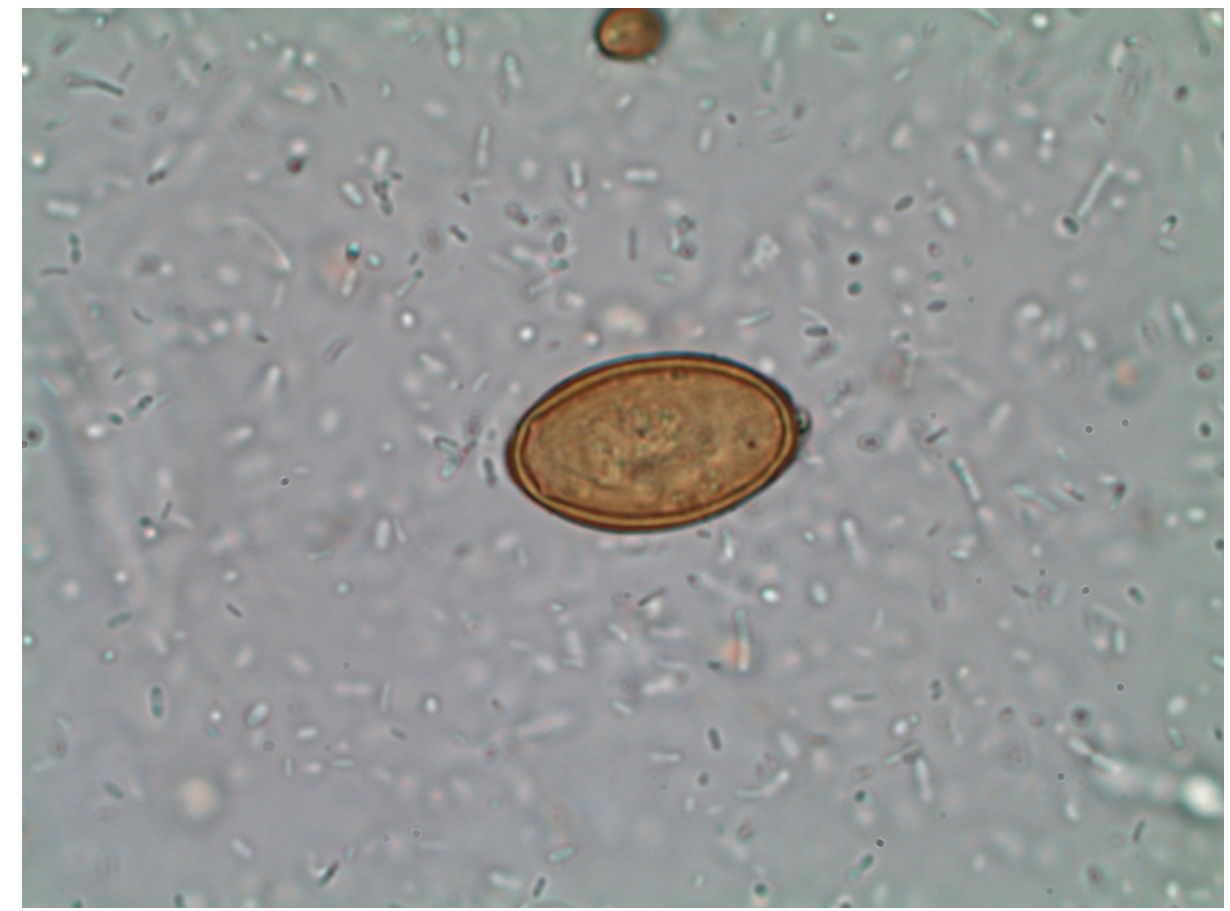

Figur 2 H. heterophyes-egg. Foto: John Olav Alvsvåg

pattedyr infiseres - hunder, katter, rotter, rever, ulver, mennesker og ulike fugler. Metacercariene klekkes i tynntarmen, der de suger seg fast og har sitt tilholdssted.

\section{Patofysiologi}

Infeksjon med Heterophyes er oftest asymptomatisk. Det er gjerne immunsvekkede eller personer med et høyt antall marker som får symptomer, som vanligvis debuterer 1-2 uker etter inntak av infisert fisk (5).

Marken kan penetrere tynntarmsveggen og forårsake sår og overflatiske nekroser. Dette kan gi kolikk og mukoid diaré (5). Dyspepsi er også et vanlig symptom. Det er rapportert tilfeller der egg er spredt hematogent og har forårsaket små infarkter og inflammasjon $\mathrm{i}$ andre organer, som lunge, hjerte og hjerne (12).

\section{Utredning}

En vanlig og enkel markør som gir mistanke om parasittose er eosinofili (1). Prøven er imidlertid ikke alltid forhøyet ved heterophyiasis, slik den heller ikke var hos vår pasient. Ved mistanke om infeksjon med humanpatogene tarmikter kan egg påvises ved mikroskopi av konsentrert feces ved formalin-eter-metode.

Eggene fra Heterophyes er små, ovale og brune, med embryo og operculum/lokk. De er 28-30 $\mu \mathrm{m}$ lange og 15-17 $\mu \mathrm{m}$ brede og likner egg av andre humanpatogene ikter (f.eks. arter av Clonorchis, Opisthorchis og Metagonimus (13). De skiller seg fra opisthorchisegg ved at de er mer ovale med mindre markant operculum (mangler «skuldre») og er uten ytre utydelig lag. Immunologiske og serologiske tester som kan bekrefte diagnosen er stort sett bare brukt i forskningssammenheng.

Mikroskopi av feces hos vår pasient viste seg å være en viktig og kostnadseffektiv analyse. Reiseanamnesen var viktig i den sammenheng. Hvis riktig diagnose ikke var blitt funnet, ville hun sannsynligvis vært henvist videre til annen utredning og vært syk inntil markene hadde dødd ut av seg selv. Det finnes ikke gode data om deres levetid, men at de ble funnet ett år etter besøk i endemisk område hos vår pasients samboer, viser at den kan overstige ett år.

Mange laboratorier har innført strengere seleksjon av prøver hvor der utføres mikroskopisk analyse av egg og cyster i feces, ettersom dette er en ressurskrevende prosedyre. Før mikroskopi må prøven forbehandles med en konsentrasjonsteknikk, og en erfaren mikroskopør bruker gjerne 20 minutter på å vurdere hver prøve. Sensitiviteten for å oppdage lettere trematodeinfeksjoner er relativt lav (7), derfor anbefales det å sende inn tre prøver med noen dagers mellomrom.

For å kunne prioritere hvilke prøver som skal mikroskoperes, kreves som regel at rekvirerende lege begrunner behovet for denne analysen ved å fremlegge opplysninger som taler for parasittinfeksjon. Slike forhold kan være eksponering gjennom forurenset mat/vann i Norge eller ved utenlandsreise, påviste tilfeller i familie/reisefølge, adopsjon/ immigrasjon fra endemisk område eller langvarige symptomer på tross av negativt resultat etter dyrking av tarmpatogene bakterier. 
Med mer moderne metoder som hurtigtester, PCR og ELISA, som noen laboratorier tilbyr, vil man bare oppdage de spesifikke parasittene de er designet for og vil således overse mer sjeldne parasitter dersom man ikke også mikroskoperer. Infeksjon med Heterophyes er ikke meldepliktig til MSIS, og det finnes ingen oversikt over forekomsten i Norge. Parasitten er ikke tidligere påvist ved vårt sykehus, og vi antar at forekomsten av symptomatisk heterophyiasis er meget liten.

Pasienten og hennes samboer hadde begge fått infeksjon med Heterophyes, men bare pasienten ble syk av dette. Den symptomfrie samboeren fikk påvist infeksjonen nesten et år etter eksponeringen. Det er usikkert hva som førte til forskjellig klinisk presentasjon hos disse to, men det det illustrerer den variable symptomatologien infeksjonen kan gi og at iktene kan leve i tarmen i ett år eller mer. Ulik infeksiøs dose, og dermed forskjellig antall mark som slår seg ned i tarmen, kan muligens forklare denne variabiliteten, men ulik individuell immunrespons eller forutgående immunsuppresjon spiller sannsynligvis en viktig rolle.

\section{Behandling}

Medikamentet som vanligvis brukes mot Heterophyes heter praziquantel (4). Det er mest brukt og best kjent for sin effekt mot schistosomiasis. Medikamentet kan skaffes ved at legen sender søknad om registreringsfritak og apoteket bestiller det inn fra grossist når pasienten kommer med resept. Det har få kjente bivirkninger, men kvalme, abdominalt ubehag, svimmelhet og hodepine kan fore- komme (4). Der finnes ingen randomiserte studier for evaluering av behandlingseffekt og optimal dosering, men lavere doser, ned mot $25 \mathrm{mg} / \mathrm{kg}$ som enkeltdose, er sannsynligvis effektivt mot Heterophyes (5).

Behandling av asymptomatiske personer er ikke nødvendig ut fra smittevernhensyn Norge, da eggene må gjennomgå utviklingsstadier i sine mellomverter (snegler og fisk som ikke finnes i Norge) for å bli infeksiøse. Behandlingen er kostbar, men vår erfaring er likevel at de fleste som får påvist innvollsmark, ønsker behandling.

Pasienten og pasientens samboer har gitt samtykke til at artikkelen blir publisert.

\section{Kurt Hanevik (f. 1968)}

er ph.d. og spesialist i infeksjonsmedisin. Han tok doktorgraden på langtidsvirkninger etter Giardia-infeksjon i 2010 og har bred internasjonal erfaring fra arbeid i utviklingsland. Forfatter har fylt ut ICMJE-skjemaet og oppgir ingen interessekonflikter.

\section{John Olav Alvsvåg (f. 1956)}

er fagbioingeniør i parasittologi. Han har sju års bred internasjonal erfaring fra laboratoriearbeid i Afrika og Asia.

Forfatter har fylt ut ICMJE-skjemaet og oppgir ingen interessekonflikter.

\section{Ketil Kvanum Sund (f. 1972)}

er spesialist i allmennmedisin og fastlege.

Forfatter har fylt ut ICMJE-skjemaet og oppgir ingen interessekonflikter.
Litteratur

1. Norsk legemiddelhåndbok. Oslo: Foreningen for utgivelse av Norsk legemiddelhåndbok, 2011. www.legehandboka.no/mage-tarm/symptomer og-tegn/diare-kronisk-2266.html (13.6.2013).

2. Gardner TB, Hill DR. Treatment of giardiasis. Clin Microbiol Rev 2001; 14: 114-28.

3. Ramakrishna BS, Venkataraman S, Mukhopadhya A. Tropical malabsorption. Postgrad Med J 2006; 82: $779-87$

4. Norsk legemiddelhåndbok. Oslo: Foreningen for utgivelse av Norsk legemiddelhåndbok, 2011. www.legemiddelhandboka.no/Legemidler/35371 (13.6.2013)

5. Leder K, Weller PF. Intestinal flukes. UpToDate 20.9 database. www.uptodate.com/contents/ search (25.9.2012)

6. Fried B, Graczyk TK, Tamang L. Food-borne intestinal trematodiases in humans. Parasitol Res 2004; 93: 159-70.

7. Fürst T, Sayasone S, Odermatt P et al. Manifestation, diagnosis, and management of foodborne trematodiasis. BMJ 2012; 344: e4093.

8. Gryseels B. Schistosomiasis. Infect Dis Clin North Am 2012; 26: 383-97.

9. Holm PI, Kristoffersen EK. A Scandinavian case of domestically acquired human fascioliasis. Scand J Infect Dis 2002; 34: 548-50.

10. Roberts L, Janovy J. Foundations of parasitology. 8. utg. New York: McGraw-Hill, 2009: 291-2.

11. Lobna SM, Metawea YF, Elsheikha HM. Prevalence of heterophyiosis in Tilapia fish and humans in Northern Egypt. Parasitol Res 2010; 107: 1029-34

12. Elsheikha HM. Heterophyosis: risk of ectopic infection. Vet Parasitol 2007: 147: 341 -2.

13. Cheesbrough M. District Laboratory Practice in Tropical Countries. Cambridge: Cambridge University Press, 2005: 226

Mottatt 17.1. 2013, første revisjon innsendt 9.4 2013, godkjent 26.9. 2013. Redaktør: Merete Kile Holtermann.

\section{Kommentar}

\section{Kortreist mat på eksotisk ferie}

Kurt Hanevik og medarbeidere beskriver en pasient med diaré forårsaket av trematoden Heterophyes heterophyes. Sannsynligvis ble kvinnen smittet etter inntak av sushi på ferietur til et nordafrikansk land. Heterophyes heterophyes er vanlig forekommende i blant annet Egypt og ellers i Midtøsten og i deler av Asia, men påvises sjelden utenfor endemiske områder.

Smitte til mennesker skjer gjennom inntak av ferskvanns- og brakkvannsfisk som ikke er tilstrekkelig varmebehandlet. De fleste som smittes får ingen symptomer. Diagnosen stilles ved mikroskopi av feces, men eggene er ofte få og vanskelige å skille fra andre humanpatogene ikter, og morfologisk artsbestemmelse er kun mulig ved funn av voksne parasitter (1). Det er beskrevet store lokale forskjeller i prevalens. Prevalensen avhenger blant annet av lokal utbredelse av mellomverter samt lokale matvaner og hygieniske forhold $(1,2)$. En nøyaktig reiseanamnese og kunnskap om lokal forekomst kan dermed være av stor betydning for å kunne stille riktig diagnose (3).

I de senere år har man på verdensbasis observert en generell økning i zoonoser overført fra fisk, og trolig er det store mørketall (2). Flere forhold nevnes som mulige forklaringer, blant annet endringer i klima, demo- grafiske endringer, internasjonal handel med fisk og fiskeprodukter og økt konsum av rå fisk også i land der man ikke har tradisjoner for slike matretter $(1,4)$. Globaliseringen øker, og i Norge er det stadig flere som reiser på ferie til eksotiske steder i Afrika og Asia. Samtidig innlemmes retter som carpaccio, sushi og sashimi i norske matvaner. Selv om sykdommen heterophyiasis neppe blir noe stort helseproblem i Norge, er det mulig vi vil se en økning av parasittære tarmsykdommer også her hjemme.

Mikroskopisk identifikasjon av parasitter i feces er en ressurskrevende analyse, og korrekt diagnostikk krever øvelse og erfaring. 